\title{
CAMTA1 wt Allele
}

National Cancer Institute

\section{Source}

National Cancer Institute. CAMTA1 wt Allele. NCI Thesaurus. Code C101441.

Human CAMTA1 wild-type allele is located within 1p36.31-p36.23 and is approximately $984 \mathrm{~kb}$ in length. This allele, which encodes calmodulin-binding transcription activator 1 protein, plays a role in transcriptional regulation. A chromosomal translocation involving this gene and the WWTR gene may be associated with epithelioid hemangioendothelioma. 